\title{
A CONTRIBUTION TO THE EXPERIMENTAL STUDY OF FEVER.
}

\author{
By JUDAH LEON JONA, D.Sc. (Adel.), M.D., B.S. (Melb.). \\ Beit Memorial Research Fellow, 1913-14. \\ (From the Lister Institute.)
}

\section{Historical.}

The condition of Pyrexia, associated with the febrile state, is a phenomenon which has been noted from the very earliest times, but only since the latter half of the last century has the experimental method been brought in to determine the cause of a phenomenon which had previously been a field of speculation only. The very old ideas can be passed over, but in the last century Johannes Müller regarded fever as a reflex process while Virchow (1853) looked upon fever as a neurosis-the condition being considered analogous to a paralytic state, a failure of the control of the vital functions of the body--while it is interesting to note that Traube $(1855,1864)$ and Traube and Jochman (1855) at this time determined an increase in the elimination of nitrogen from the body in fever. Both Virchow and Traube assumed the existence of a fever-producing agent, but did not proceed to elucidate its nature or origin.

Panum (1855) extracted from putrifying solutions a heat-stable body, insoluble in alcohol but soluble in water, of which 0.012 grain would kill a small dog, producing febrile disturbances and symptoms of acute infection.

In 1864 Otto Weber and in 1866 Billroth introduced septic material into circulating blood or cellular tissue and they were the first to compare the artificial fever thus induced with ordinary "surgical" fever. They found that the inoculation of putrefactive material, whether of animal or vegetable origin, led to the production of a febrile state reaching its maximum in $2-28$ hours. It was also shown that the 
products of acute inflammation produced fever under similar conditions and that these products owed their infective properties to the presence of "microphytes." It was concluded that the fever was therefore due to these bodies.

Hermann (1866) obtained results similar to those of Panum and concluded that the body was a protein and worked like a ferment. Burdon Sanderson (1867) prepared from putrid meat a substance, which he called Pyrogen, because, on injection, it produced fever, but it lost its effect on filtration through porcelain. It did not, he says, contain live bacteria, as these were killed by the previous addition of alcohol.

In the same year it was shown by Frese (1866) that the feverproducing properties of the products of decomposition and of inflammatory tissue destruction remain unimpaired after boiling and subsequent filtration.

These results were confirmed by E. Bergmann (1868).

Similarly a febrile reaction has been obtained by different observers after the injection of various specific organisms; by Roussy (1910) with yeasts, by Buchner (1891) with Pneumobacillus, B. pyocyaneus and B. prodigiosus; Klemperer (1892) with Pneumococcus, B. pyocyaneus, B. coli and B. anthracis; by Römer (1891) with $B$. pyocyaneus and Pneumobacillus, while Hort (1913) investigating emulsions of dead bacteria (vaccines) has found that a fever reaction can fairly constantly be obtained after the injection of $B$. typhosus, B. coli, $B$. influenzae, B. pestis, M. melitensis, M. catarrhalis, V. cholerae, Acne bacillus and certain strains of Staph. albus, S. citreus and S. aureus, while there is a large group of bacteria whose vaccines rarely, if ever, induce fever when injected into rabbits.

Five hours after the injection of $\cdot 250 \mathrm{gm}$. of Tubercle bacillus into the normal human being, Koch (1890) noticed shivering and rise in body temperature.

Edelberg (1880), Hildebrandt (1890), Hueppe (1893), Rouques (1893), Krehl (1897) and Zupnik (1903) showed that a febrile reaction followed the injection of various proteins and ferments-though pure enzymes prepared under the direction of Kühne were shown by him to have no thermogenetic property, although commercial enzymes had. Kühne (1893) prepared from Koch's Tuberculin a "deutero-albumose" which, on injection into the body, induced fever, while a fever-producing albumose had also been obtained by Krehl (1897) from the Bacillus coli communis, and Matthes (1895) showed that the albumose obtained 
from peptic digestion of ordinary proteins produced a similar fever to that produced by the albumose from Tuberculin particularly in tuberculous subjects.

In addition to the above were the common surgical experiences of the fever, which sometimes supervened after more or less severe internal haemorrhage, transfusions of blood, simple fracture, injection of sterile tissue extracts and after severe superficial burns and scalds in which bacterial infection from without could be excluded. In these cases the fever was believed to be due to the liberation in the body of the products of the wholesale breaking down of cells of the body itself.

Following the teaching of Edelberg (1880) and others, the rise in temperature was attributed to the absorption of Fibrin-ferment: Latterly, however, the work of Hort and Penfold (1911-1912) on the effects of injection of ordinary distilled water, in which organisms had propagated to some extent, has shown how careful we must be in accepting the results of the injection of extracts of tissues or other bodies made with such sterilized water. These authors have shown that when ordinarily water after it is sterilized is injected intravenously into rabbits (injection dose from 1 in 200 of body weight, i.e. 10 c.c. to a rabbit of $2000 \mathrm{gm}$. weight), the result is usually a short febrile reaction, whereas the injection of pure sterile distilled water, carefully distilled from glass (after the whole apparatus has been thoroughly cleaned out with cleaning fluid-Potassium Bichromate and Sulphuric Acid), produces not a rise, but a fall in the body temperature. When this water is contaminated to varying degrees with some varieties of living or killed bacterial cultures, the fall is, they found, replaced by a plateau and with greater additions by a rise, while with large additions of the same organisms, there is a marked fall in temperature (sometimes preceded by a small rise) ending in death in many cases. They also demonstrated the thermostability of the pyrogen, as well as the fact that it will pass hardware filters, though only to a small extent when packed with gelatin.

These results have been confirmed in the main by other and independent observers. Recently Friedberger (1911) and his pupils have published several papers on the nature of the fever reaction which they regard as of the nature of anaphylactic shock.

Sebastiani (1912) acting along lines previously pursued by Centanni (1894) and Kiliani (1911) has endeavoured to isolate the pyrogen from extracts of bacteria. Using Bacillus prodigiosus he takes a 3 day broth culture, and kills the bacilli by heating on the water-bath for 15 minutes, 
after faintly acidulating with acetic, hydrochloric or sulphuric acid. He then allows the culture to stand for about 15 days under toluol, precipitates with acetate of lead and removes the excess of lead acetate from the filtrate with $10 \% \quad \mathrm{Na}_{2} \mathrm{SO}_{4}$. The colourless liquid thus obtained he calls Pyrotoxin. By giving repeated doses of this pyrotoxin at definite intervals and varying doses, he obtained various types of fever-continuous, remittent, intermittent, quotidian-and obtained remission of the fever by lysis or by crisis. He therefore argued that all types of fever were due to one pyrotoxin which acted differently in different cases.

In some of his experiments Sebastiani further purified his pyrotoxin solution by precipitation with alcohol. This removes some substances having a depressant action which may mask the action of the pyrogen itself.

\section{The Author's Investigations.}

In the present investigation Bacillus coli communis has been prinoipally employed though occasionally $B$. typhosus has also been used. The animals used in all the experiments recorded were medium sized rabbits. The normal temperature of rabbits has been dealt with by Frothingham and Minot (1912), who showed that it varied irregularly over a span of $2.5^{\circ} \mathrm{F}$. below $103.5^{\circ} \mathrm{F}$.

Methods used for the Induction of Fever. At first the method employed by Hort and Penfold (1912) was used, namely, the injection into an ear vein of 10 or 15 c.c. of pure distilled water to which a definite amount of a broth culture of $\boldsymbol{B}$. coli communis or $\boldsymbol{B}$. typhosus was added.

In later experiments, however, the substance used was injected in 1 or 2 c.c. of Ringer's solution and, instead of a broth culture, a preparation of bacteria which could be kept in a dry state was employed.

This was made as follows:

A 24 hour culture of Bacillus coli communis on Broth Agar was scraped off with the aid of a little sterile distilled water, and centrifuged-the bacteria not being killed before centrifuging. The bacteria were washed, and some of the bacterial paste left at the bottom of the centrifuge tube was taken and weighed, dried, and weighed again to determine the total amount of dry solids present in a given weight of the paste. The weight of dry solids is taken as representing the amount of dried bacterial bodies present. The remainder of the bacterial paste was then mixed with about an equal weight of anhydrous $\mathrm{Na}_{2} \mathrm{SO}_{4}$, and was put aside to set. The object of adding the anhydrous 
sodium sulphate was to obtain a preparation which would be perfectly dry. Anhydrous sodium sulphate $\left(\mathrm{Na}_{2} \mathrm{SO}_{4}\right)$ in the cold combines with water, forming the hydrated compound, $\mathrm{Na}_{2} \mathrm{SO}_{4}$. Aq. This, when warmed to $35^{\circ} \mathrm{C}$., gives up its water of crystallisation forming $\mathrm{Na}_{2} \mathrm{SO}_{4}$ in solution, and on cooling again sets to $\mathrm{Na}_{2} \mathrm{SO}_{4} \cdot 10 \mathrm{Aq}$.

The bacterium-sulphate paste was warmed and cooled several times and was then, when warm, spread out on a plate to cool. When cool it was powdered up in a mortar and the powder thus obtained was used for injection-the dose being usually suspended in 1 c.c. warm Ringer's solution. The powder prepared as above contained $3.8 \%$ of dry bacterial substance. This powder was used in most of the experiments, and six months after its preparation was still potent. In other experiments the pyrotoxin as prepared by Sebastiani (1912) was used.

Site of injection. Aseptic methods were used throughout. Generally the injection was intravenous, though similar results were obtained after hypodermic, intramuscular and intraperitoneal injection. The response to the injection was generally sooner after intravenous injection. The fluid injected was always warmed to body temperature before injection.

Effect of Dosage. A number of experiments were performed to determine the relationship, if any, existing between the dose of bacterial material injected and the degree of bodily reaction.

Charts 1, 2 and 4 represent such sets of experiments and it is of interest to note the effects (in Chart 1) in the same animal of an injection of the same quantity ( 15 c.c.) of pure distilled water, containing gradually increasing doses of bacteria. The effects of increasing the amounts of dry bacterial substance injected in a minimum fixed amount of Ringer's solution is well seen in Charts 2 and 4 . It will be noticed in all the charts that, with minimum doses, there is produced a rise in temperature which reaches its maximum in 1-2 hours, and then quickly comes back to normal. The effect increases with the dose to a certain point and, on further increasing the dose, the response is a "notched" temperature, i.e., after a single dose the temperature rises, then falls to or below normal and then rises again, sometimes as high as or higher than the first rise, and then falls to normal. With larger doses the temperature may rise very little but the animal is manifestly ill and exhibits the condition described below. On further increasing the dose the temperature falls (sometimes preceded by a slight rise) and the death of the animal occurs in an hour when a sufficiently large dose is injected. 


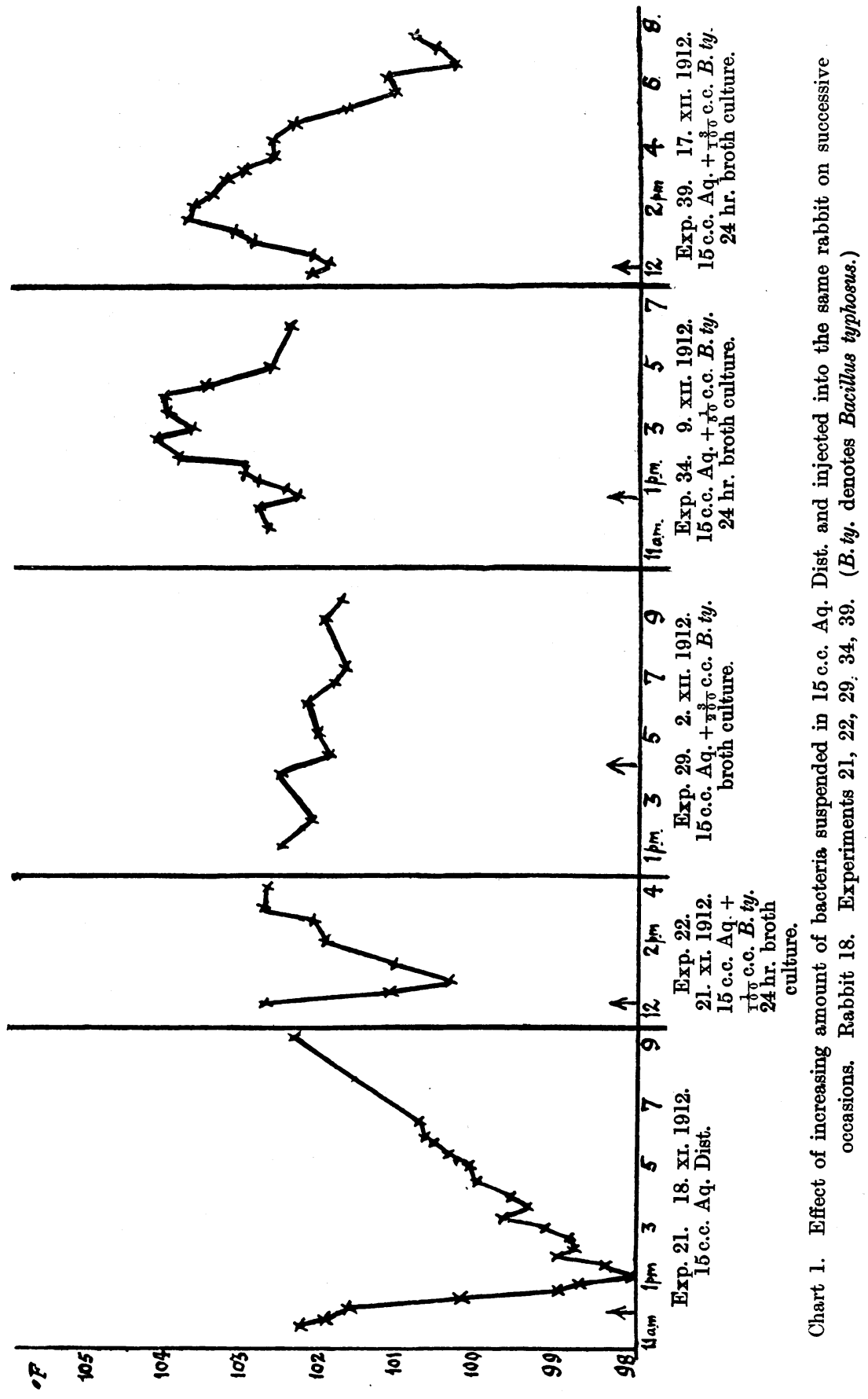


J. L. JoNA
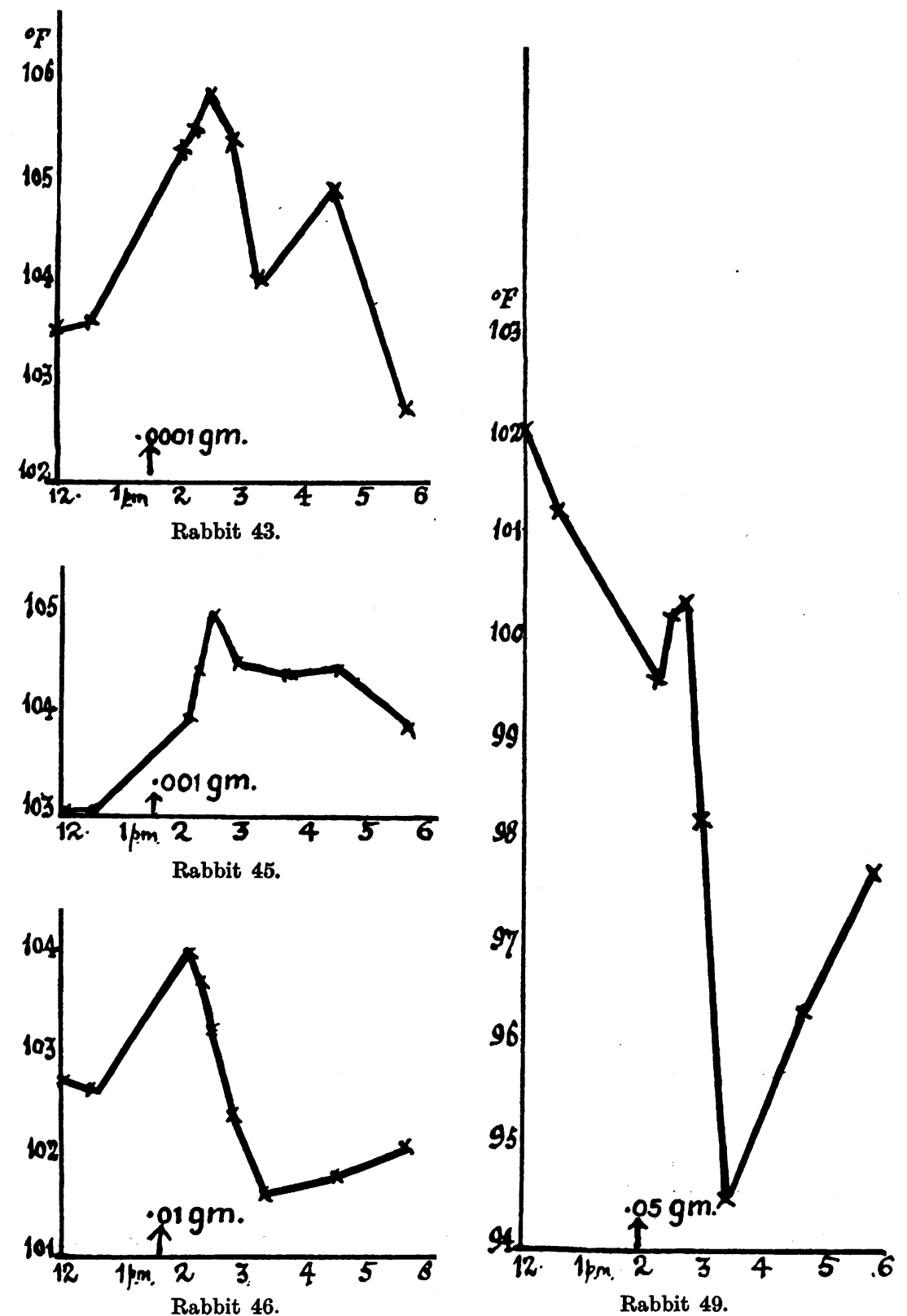

Chart 2. B. coli communis=Sulphate powder. Exp. 52. 23. I. 13. Temp. of air dry $13.7^{\circ} \mathrm{C}$., wet $11.5^{\circ} \mathrm{C}$. Sulphate bacteria powder containing $3 \cdot 8^{\circ}$ dry bacterial substance. Dose in each rabbit injected in 1 c.c. warm Ringer's solution. 
General Effect on Animals of a Single Dose. The animals reacted to the injection of the pyrogen, either with a temporary pyrexia or a collapse. They showed general signs as well as an effect on the temperature; quietness, lethargy, torpor, sometimes weakness in the legs and even in some cases, inability to stand. More or less marked
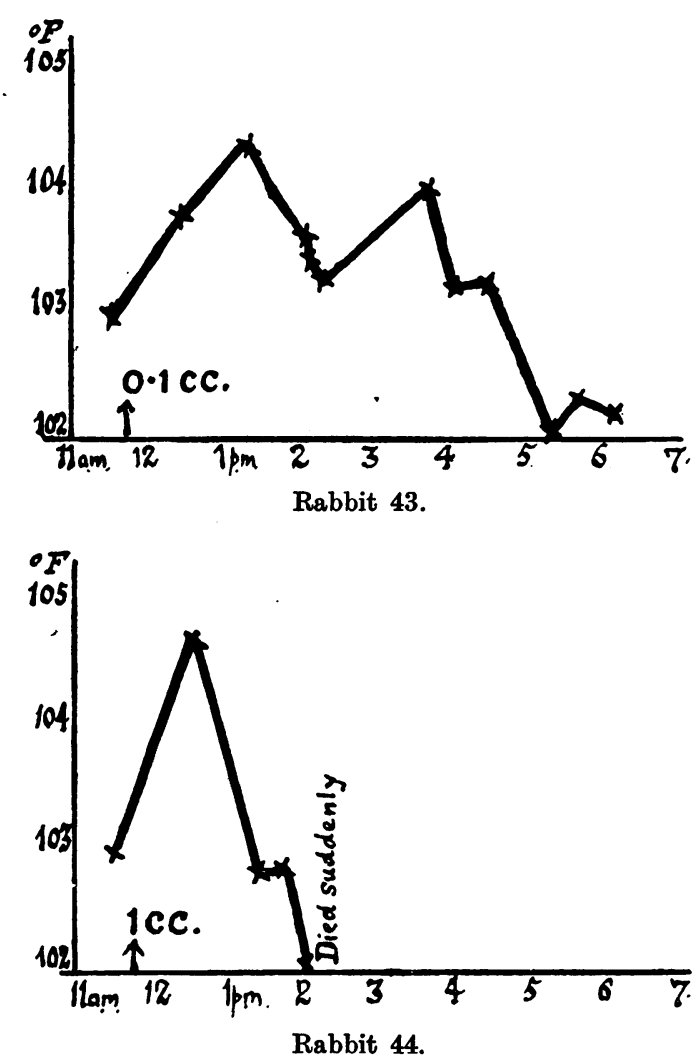

Chart 3. Injection of Bacterium-free supernatant fluid. Exp. 48. 20. I. 13. Supernatant fluid ( 280 c.c.) from $2 \cdot 84$ gms. dry bacteria; at 2 p.m. No. 44 died suddenly ; at 2.10 p.m. No. 43 toppled over and could not stand but regained power in legs in about 3 minutes, at 3.45 p.m. still weak in the legs. Rabbit 43 injected with $0 \cdot 1$ c.c. in 1 c.c. Ringer; rabbit 44 injected with 1 c.c.

Diarrhoea generally followed in an hour or so, and sometimes even the passage of blood by the rectum, which could not be entirely accounted for by the frequent insertions of the thermometer into the rectum.

The exact time relations differed in different animals and with different doses. Generally some effect was noticeable within an hour, 
and usually the animal was apparently quite normal again in 6 or 7 hours. In some, however, the effects lasted considerably longer. Types of the different effects are illustrated in the charts.

In one case, Rabbit 44, Experiment 48, Chart 3, the animal died with a temperature of $102^{\circ} \mathrm{F}$. within $2 \frac{1}{2}$ hours of the injection, the temperature in the meantime having risen to $104 \cdot 7^{\circ} \mathrm{F}$.

This animal received an injection of the bacterium-free supernatant fluid obtained by centrifuging a suspension of Bacillus coli communis in distilled water.

Idiosyncrasy of Animal used. In many cases the dose was repeated after an interval of several days. No marked alteration in the response was given. Friedberger and Mita (1911) say that a previous dose renders the animal sensitive to a later dose, but other observers (Royal Commission on Tuberculosis 1913) have not found this to be the case.

In many cases different animals of approximately equal weight did not give the same febrile reaction with the same dose. One animal giving a simple rise and fall, another a "notched" temperature and a third a temperature approaching the "plateau" type.

It is of interest to note that the fever reaction is best obtained with young adults (rabbits of about $2000 \mathrm{gms}$. weight). With older (heavier) individuals a dose of pyrogen sufficient to produce a rise in temperature in the smaller animal had no effect, while the larger dose, which in this animal produced a marked fall, generally produces a slight rise in smaller and younger animals.

The Royal Commission on Tuberculosis (1913) found that with normal bovines after the injection of Tuberculin either a rise or fall in temperature occurred, but in the majority of animals no effect was obtained. This result, however, is quite possibly due to the effect of the dosage, variations in which were not investigated to any extent.

In non-tuberculous rabbits with the doses used, no effect was obtained, while in tuberculous rabbits the results varied. Here again the results obtained may have been due to wrong dosage or to an idiosyncrasy on the part of the rabbit.

With monkeys the results were varied, but on p. 79 of the Commission's Report (1913) the temperature of normal monkey 114, chart 42 , is seen to drop $4 \cdot 7^{\circ} \mathrm{F}$. in 6 hours after an injection, while in chart 44, monkey 98 shows a fall of $4 \cdot 47^{\circ} \mathrm{F}$. within the 6 hours after injection. This result the authors regarded as a failure to react.

The Effect of Multiple Doses has been investigated by Hort and Penfold (1912) and by Sebastiani (1912), whose results have been 

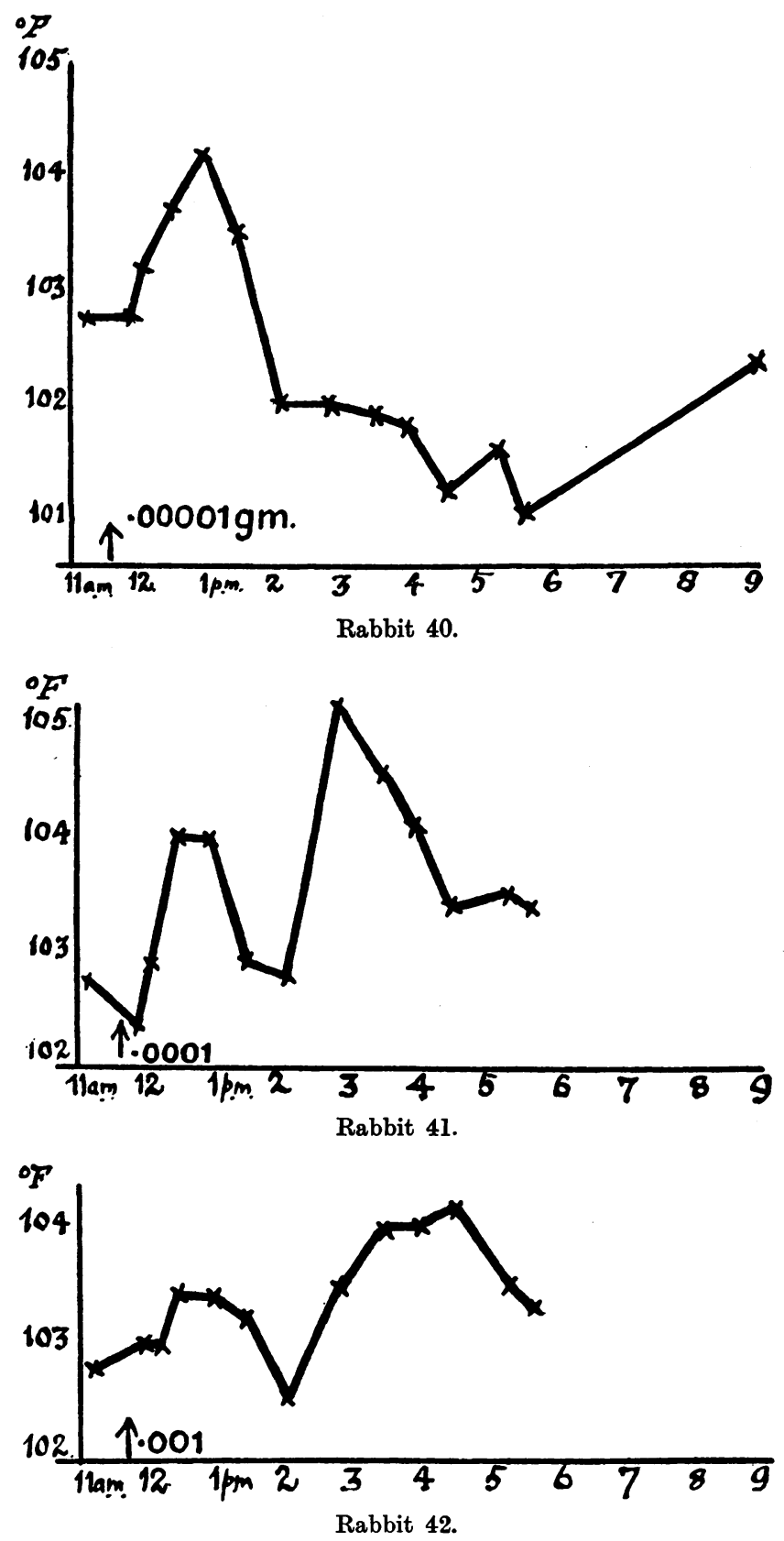

Chart 4. Ether extracted powder. Exp. 55. 27. I. 13. Temp. of air dry $14 \cdot 4^{\circ} \mathrm{C}$., wet $10 \cdot 0^{\circ}$ C. B.c.c. sulphate powder as used in Exp. 52 extracted with ether. Rabbit No. 40 injected with $0.00001 \mathrm{gm}$. B.c.c. powder (=0.000004 gm. dry bacteria) in 1 c.c. Ringer. Rabbit No. $41,0.0001$ gm. B.c.c. powder (=0.00004 gm. dry bacteria) in 1 c.c. Ringer. Rabbit No. 42, $0.001 \mathrm{gm}$. B.c.c. powder (=0.0004 gm. dry bacteria) in 1 c.c. Ringer (B.c.c. denotes Bacillus coli communis.) 
referred to above. I have also performed a few experiments on this point. Experiment 66, Chart 5, records a result which differs somewhat from Sebastiani's. On giving a series of minimal doses (i.e. doses which will produce a small effect though not the maximum) the

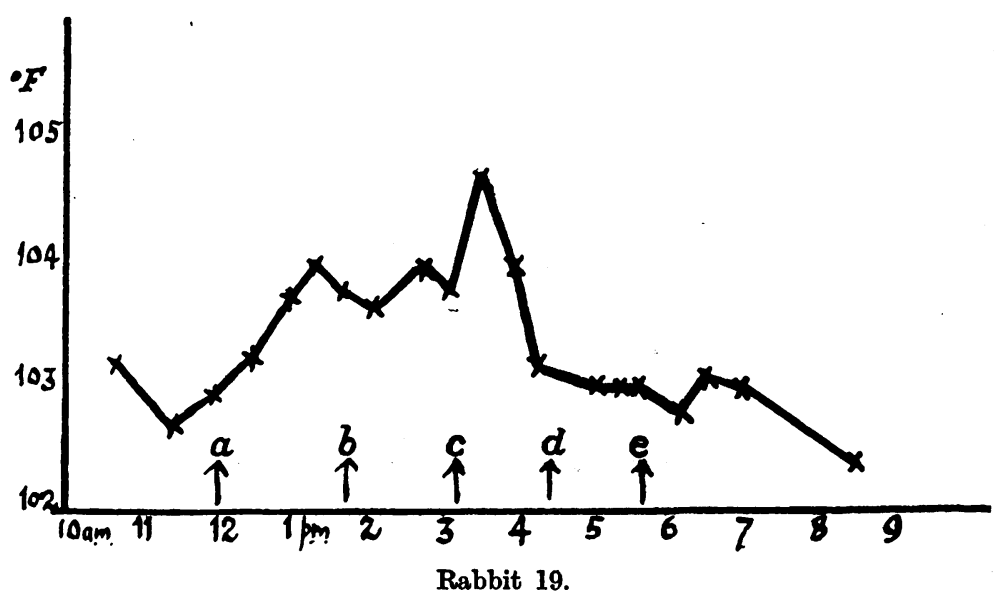

Injections: $a, 0.00002$ gm.; $b, 0.00002$ gm.; c, $0.00002 \mathrm{gm}$; $d, 0.00002 \mathrm{gm}$.; e, $0.00005 \mathrm{gm}$.

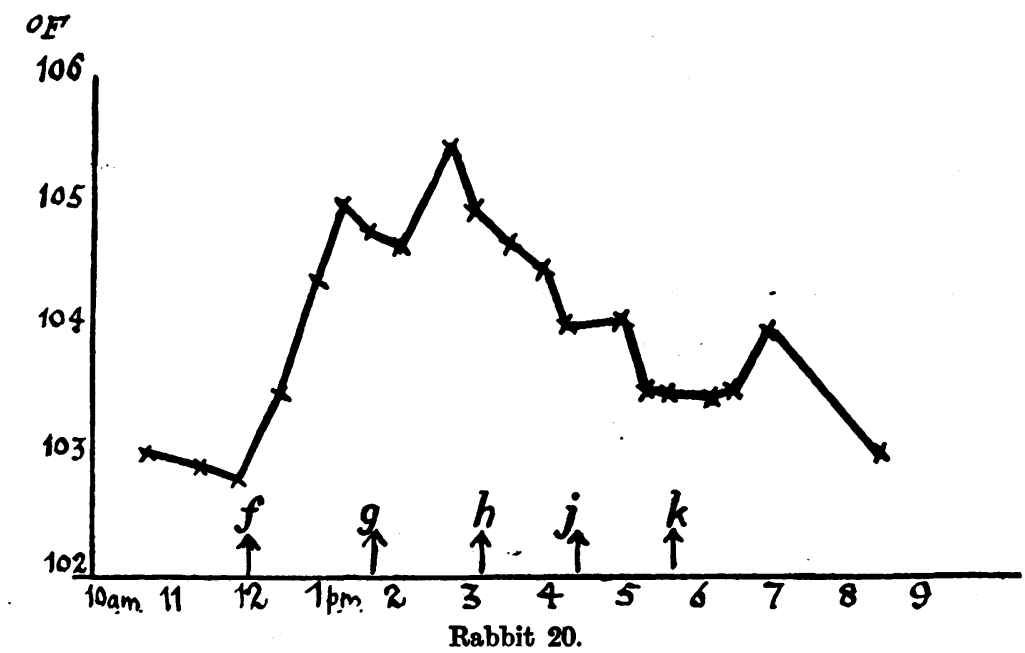

Injections: $f, 0.0001$ gm.; $g, 0.00002$ gm.; $h, 0.00002$ gm.; j, 0.00002 gm. $k, 0.00005 \mathrm{gm}$.

Chart 5. Exp. 66. 10. I. 13. Repeated injections of B. coli communissulphate powder. 
temperature (Rabbit 19) is seen to rise after each injection by steps to a point which may be regarded as the maximal response and then begins to fall to normal in spite of further injection of a second previously effective dose and of a dose which previous experiment had shown was about the optimum for a "spike" temperature.

A similar effect is seen with Rabbit 20 , in which the maximum temperature is soon reached by giving a large initial dose of pyrogen, and whose temperature falls in spite of further injections.

The charts on pp. 107-117 of the Report of the Royal Commission on Tuberculosis (1913) show how the sensitiveness to Bacillus tuberculosis diminishes after each injection. A similar result was obtained by Klemperer (1892) with a body obtained from the Pneumococcus which he called Pneumoproteid.

\section{Mechanism of the Febrile Reaction.}

It is not proposed to discuss the voluminous literature upon the part taken by variation in heat loss and heat formation in the production of the increased temperature in fever. This has been recently reviewed by 0 . Loewi in his article "Pharmakologie des Wärmehaushalts" in the Ergebnisse der Physiologie (1904), p. 332, by Langlois in the Article "Fièvre" in Richet's Dictionnaire de Physiologie, Vol. vI, p. 423 (1904), and by F. Kraus in the chapter "Fever and Infection" in von Noorden's Metabolism and Practical Medicine, English translation, 1907, Vol. II, p. 120. A number of observers have however made observations on rabbits in which fever has been produced by the injection of pathogenic micro-organisms which will be briefly summarized. Senator (1873) found intense vaso-constriction of the ear vessels during the rise of temperature following injection of a culture of Swine erysipelas.

May (1893) in a series of extensive calorimetric observations on rabbits found that on the first day the heat loss oscillated round normal, but subsequently augmented to as much as $30 \%$. W. Rosenthal (1893) by thermo-electric measurements of the temperature of the skin came to the conclusion that in the first stage of the fever there was a constriction of vessels in rabbits. Nebelthau (1895), and Krehl and Matthes (1897) came to similar conclusions from calorimetric observations on rabbits. Most of Nebelthau's experiments lasted over some days. Kalinin (1897), who determined the $\mathrm{CO}_{2}, \mathrm{~N}$, and $\mathrm{P}_{2} \mathrm{O}_{5}$ output of rabbits in health, and in the febrile condition, also found that at the onset of fever no increase of $\mathrm{CO}_{2}$ production occurred. 
J. L. JoN

181
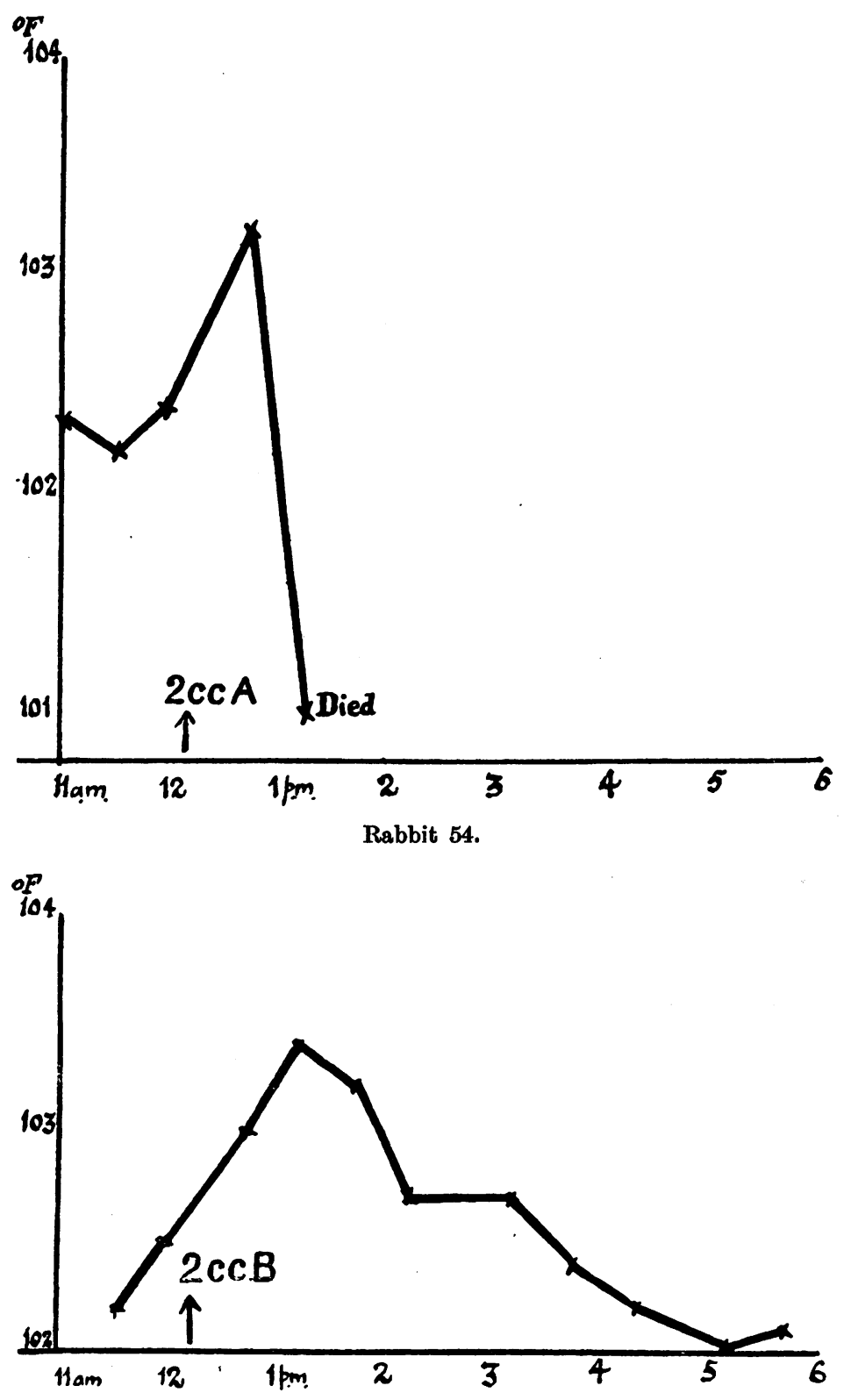

Rabbit 52.

Chart 6. Filtration of pyrogen through collodion. Exp. 83. 1. I. 13. Temp. of air dry $13 \cdot 3^{\circ} \mathrm{C}$., wet $10 \cdot 3^{\circ} \mathrm{C}$. 24 hour $B$. coli communis broth culture filtered through Berkefeld filter. $(A)=$ filtrate diluted with equal amount of water. 2 csc. injected into rabbit 54. $(B)=(A)$ filtered through $7 \%$ collodion filter at 30 lbs. per sq. in. Filtrate, 2 c.c., injected into rabbit 52. 


\section{A. Methods.}

\section{(1) Investigation of Heat Loss.}

The reaction of the cutaneous blood-vessels of the rabbit was employed in this investigation as an indication of the amount of heat lost.

The temperature of the ear of the rabbit can be used as an indicator of the condition of the skin vessels if the animal be carefully handled. The large-eared variety, which were used in this particular research, are admirable for this purpose. Their ears present a considerable part of the total body surface which not being heavily insulated as the rest of the body is used by this variety for adjustment of body temperature. The means used was a simple one, and was found sufficiently delicate. Cotton-wool was lightly plugged in the external auditory meatus. The ear was rolled into a tube and kept in this form by two light rubber bands; then a quickly registering thermometer with a very small bulb was inserted into this "ear-tube." (The thermometer would register a temperature of $37^{\circ} \mathrm{C}$. from room temperature of $22^{\circ} \mathrm{C}$. in 12 seconds.) This thermometer recorded the temperatures of the small air space in the ear, the temperature of which naturally depends on $(a)$ the temperature of the blood in the vessels of the ear; $(b)$ the temperature of the outside air, and $(c)$ the rate of blood flow through the ear. The last is largely dependent on the condition of the bloodvessels of the ear, so that as the external temperature remained nearly constant, changes in the temperature of this air space could be taken as indicating alterations in the vascularity of the ear.

The animal rested comfortably in a small wooden box throughout the experiment.

Experiments showed that, with a fairly uniform rectal temperature, the ear temperature remained fairly constant so long as the animal was comfortable and was not excited or worried, and that its rectal temperature could, by the use of ordinary care and gentleness, be taken with but little reflex disturbance of the skin vessels due to the handling. This can be seen on reference to the Charts 7 and 8 (Experiments 7 and 21 respectively). The animals used in all cases were medium sized rabbits, from about 1600 to 2400 gms. weight (except in one case, Rabbit 50, Experiment 64) and the temperature was always taken at intervals for an hour or more before the injection was given. In many cases the respiration rate was observed, but no observations were made on the actual amount of ventilation. 


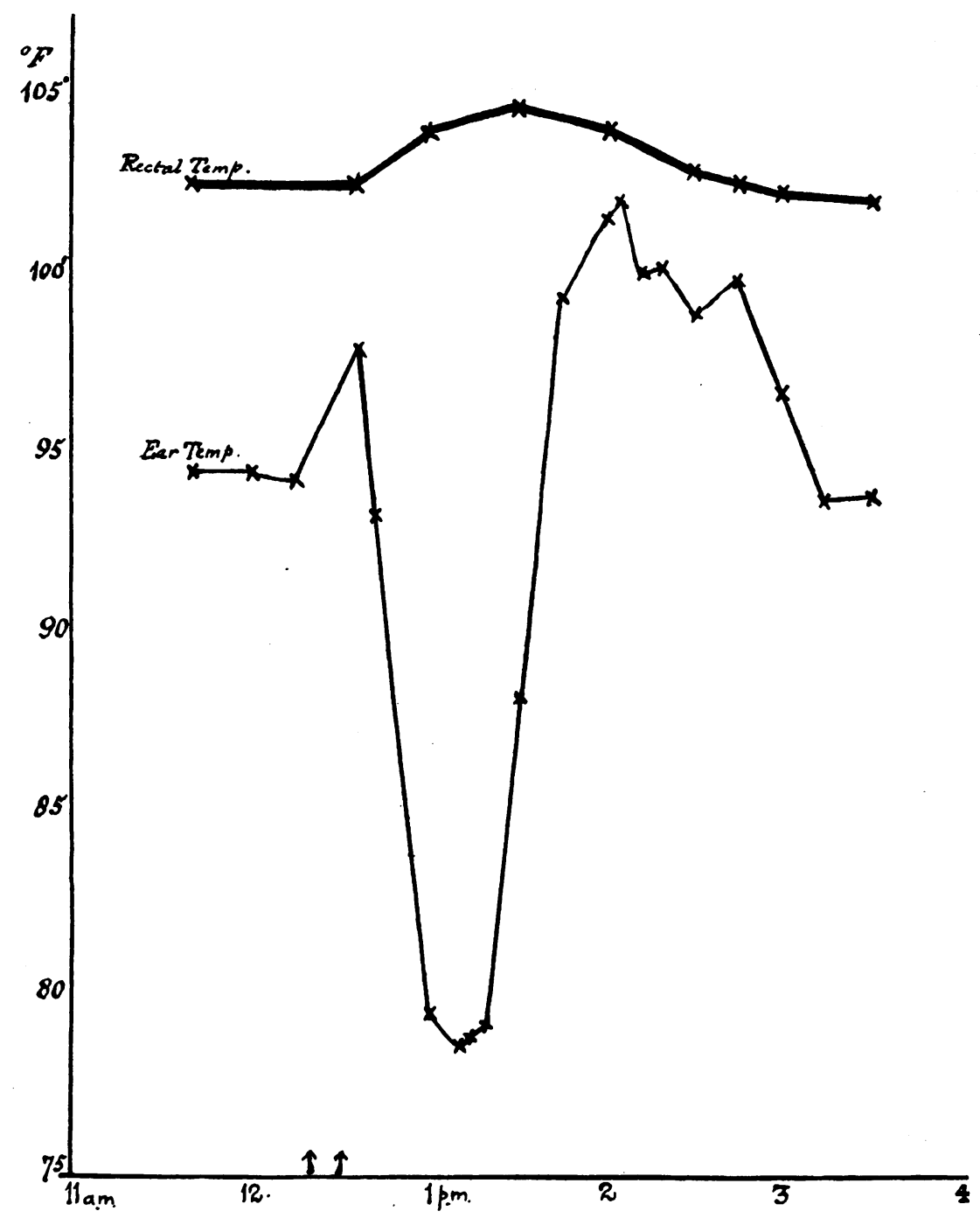

Chart 7. Exp. 7. Temp. of air $14^{\circ} \mathrm{C}$, wet bulb $11 \cdot 4^{\circ} \mathrm{C}$. Rabbit No. 6. Weight before experiment $2820 \mathrm{gms}$. Loss in weight during exper. (excluding urine and faeces) 100 gms. 12.20 p.m. injected 5 c.c. aq. dist. $+\frac{1}{200}$ c.c. 24 hr. broth B. typhosus culture. 12.30 p.m. injected 5 c.c. aq. dist. $+\frac{1}{20 \sigma}$ c.c. 24 hr. broth B. typhosus culture.

\section{(2) Heat Production.}

This was determined indirectly by measuring the $\mathrm{CO}_{2}$ production and $\mathrm{H}_{2} \mathrm{O}$ given off, and calculating the oxygen used. A modification 
of the Respiration Apparatus described by Haldane (1892) was employed. Instead of using the large glass bottle which Haldane recommends, a metal box (Fig. 1) was used. Its dimensions were $40 \times 20 \times 20 \mathrm{~cm}$., and it had a false bottom of wire gauze, on which the animal rested. Any urine passed while the animal was in the chamber collected in that part of the box below the gauze platform. Inlet and outlet air-tubes were let into opposite ends of the chamber.

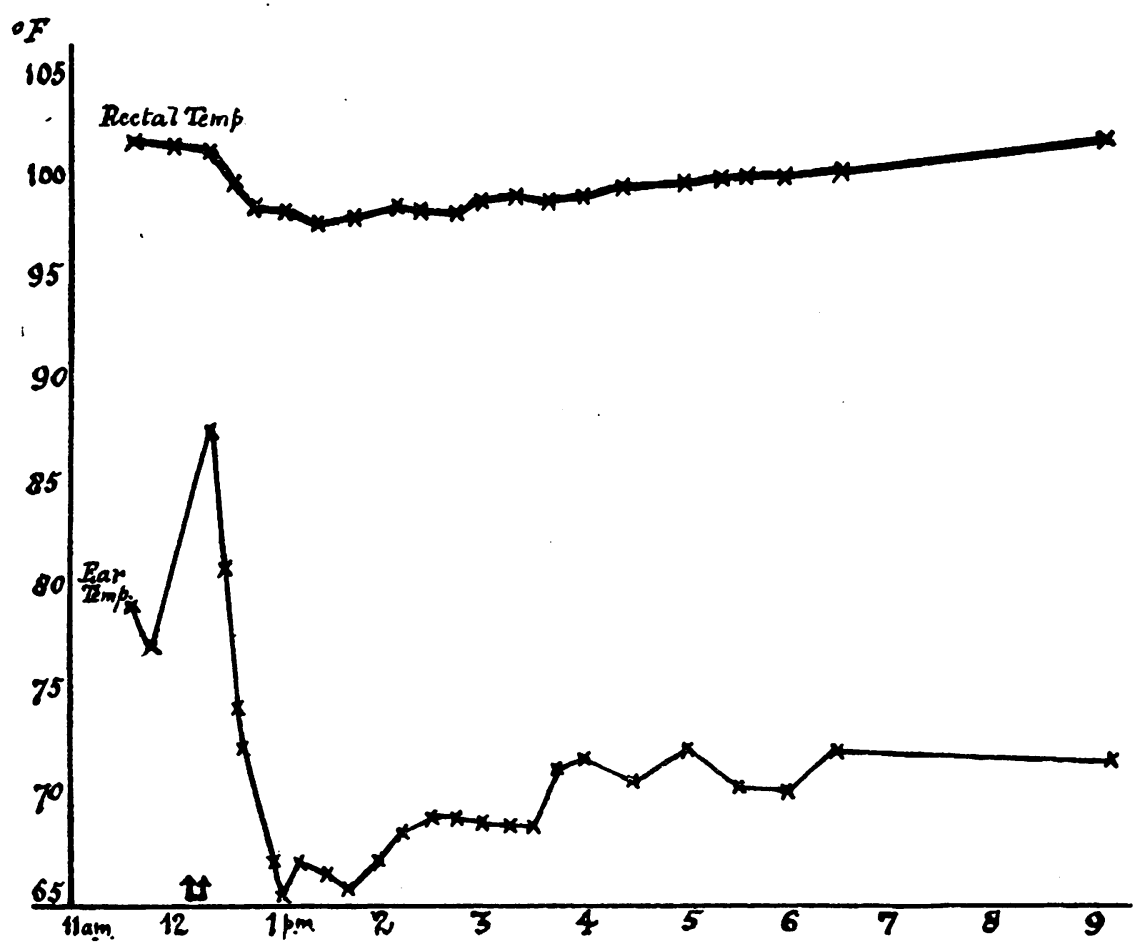

Chart 8. Exp. 21. Rabbit No. 18. Weight before 2252 gms., after 2150 gms., loss in $10 \mathrm{hrs} 102 \mathrm{gms}$. Temp. of air dry $14 \cdot 2^{\circ} \mathrm{C}$, wet $11 \cdot 0^{\circ} \mathrm{C} 12.10 \mathrm{p} . \mathrm{m} .-12.18 \mathrm{p} . \mathrm{m}$. injection of 15 c.c. of pure distilled water into ear vein.

The lid was made of thin plate glass, hermetically sealed with red lead into a metal lid the edges of which were flanged so as to fit on the top of the edges of the box. A mixture of vaseline and hard paraffin was used as cementing material. Its weight when completely sealed up was about $4150 \mathrm{gms}$.

The box was warmed before the animal was put in and the animal was kept in the chamber for half an hour before the experiment was commenced. 


\section{B. Results. \\ (1) Heat Loss.}

(1) When an intravenous injection of 10 c.c. distilled water and 1/100 c.c. 24 hour broth culture of $B$. typhosus (boiled) was given (Chart 7, Experiment 7) a rise in body temperature was produced. As the rectal temperature rose, there was a marked constriction of the ear vessels and a marked diminution in the respiratory rate. These reached their minimum before the rectal temperature reached its maximum and then, after a short plateau at this minimum value, the vessels began to dilate and the respiratory rate to increase. The ear

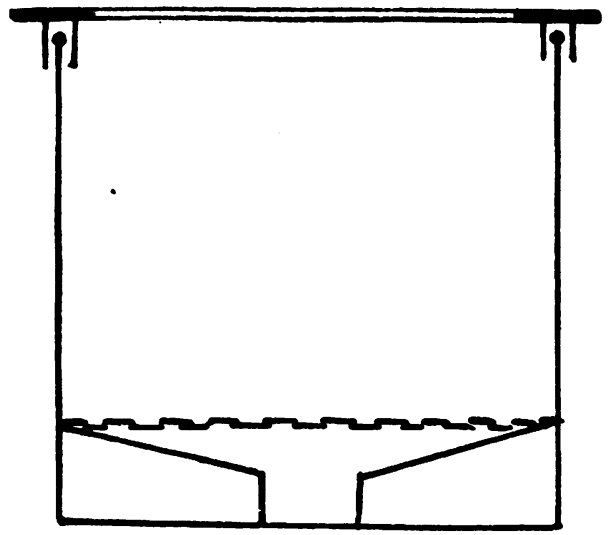

Fig. 1. Transverse Section of Box.

temperature rose above its initial value and this dilatation of the ear vessels was soon followed by a fall in rectal temperature to normal. As the rectal temperature began to fall to its initial level the ear temperature also began to fall to its initial value.

(2) When an intravenous injection of 15 c.c. (warmed) pure distilled water was given, there was a marked fall in rectal temperature (Chart 8, Experiment 21). This was accompanied by a constriction of the ear vessels and a diminution of respiratory rate and these remained at their low value even when the rectal temperature had reached its initial value again. The same effect on the ear vessels is seen in Experiment 64 , in which a fall in rectal temperature was produced by the injection of $\cdot 0011 \mathrm{gm}$. of $B$. coli communis $-\mathrm{Na}_{2} \mathrm{SO}_{4}$ powder containing $3.8 \%$ dry bacteria.

Journ. of Hyg. xv 


\section{(2) Heat Production.}

A reference to Chart 9 shows that with a rise in temperature induced by injections of suspensions of bacteria (Experiments 80 and 82 ) there is no consistent alteration in the $\mathrm{CO}_{2}$ output. In Experiment 80, $20 \%$ increase occurred during the rise of temperature, in Experiment 82 $10 \%$ less $\mathrm{CO}_{2}$ was produced. In Experiments 79 and 90 with injections of suspension of fairly large doses of bacteria, there is accompanying the fall in temperature a diminution in the $\mathrm{CO}_{2}$ output.

Experiment 87 is a more complicated one, two successive doses of Sebastiani's "Pyrotoxin" being given; and here again there is practically no effect on the $\mathrm{CO}_{2}$ output throughout the experiment and so the variations in temperature must be attributed to variations in heat loss. The $\mathrm{H}_{2} \mathrm{O}$ output being only partly derived from oxidation in the body and partly from $\mathrm{H}_{2} \mathrm{O}$ excreted or evaporated from the lungs or from evaporated urine, no deductions can legitimately be made from the observations recorded.

Seat of Action of the Pyrogen. The number of experiments on this point are limited, but on general principles it might be reasonably expected that the pyrogen exerts its action on the body by influencing the central heat regulating mechanism. This is generally regarded as being situated in or in the neighbourhood of the Corpus Striatum (Barbour, 1912).

As far as experiments on the recently "decerebrated" (dethalamate) animal can be of value in determining this point, Experiments 14 and 36 indicate that, after section of the central nervous system distal to the optic thalamus, no fever reaction results from the injection of a dose of pyrogen ordinarily sufficient to induce fever. The operation was performed under anaesthesia. After trephining the skull, an aneurism needle was passed along the tentorium and the brain stem severed below the Optic Thalamus. The brain itself was not mutilated at all.

The position of section was verified by post-mortem examination.

It is, however, questionable whether these results are of much value as the animal was more or less in a condition of shock when the pyrogen was injected.

Nature of the Fever-Producing Body. As previously cited experiments have shown, broth cultures of $B$. coli contain pyrogen, though in relatively small quantities. Similarly the washings of emulsions of this organism are also pyrogenetic, although the washings were found to be bacteria free by microscopical examination (Experiment $59 b$, 

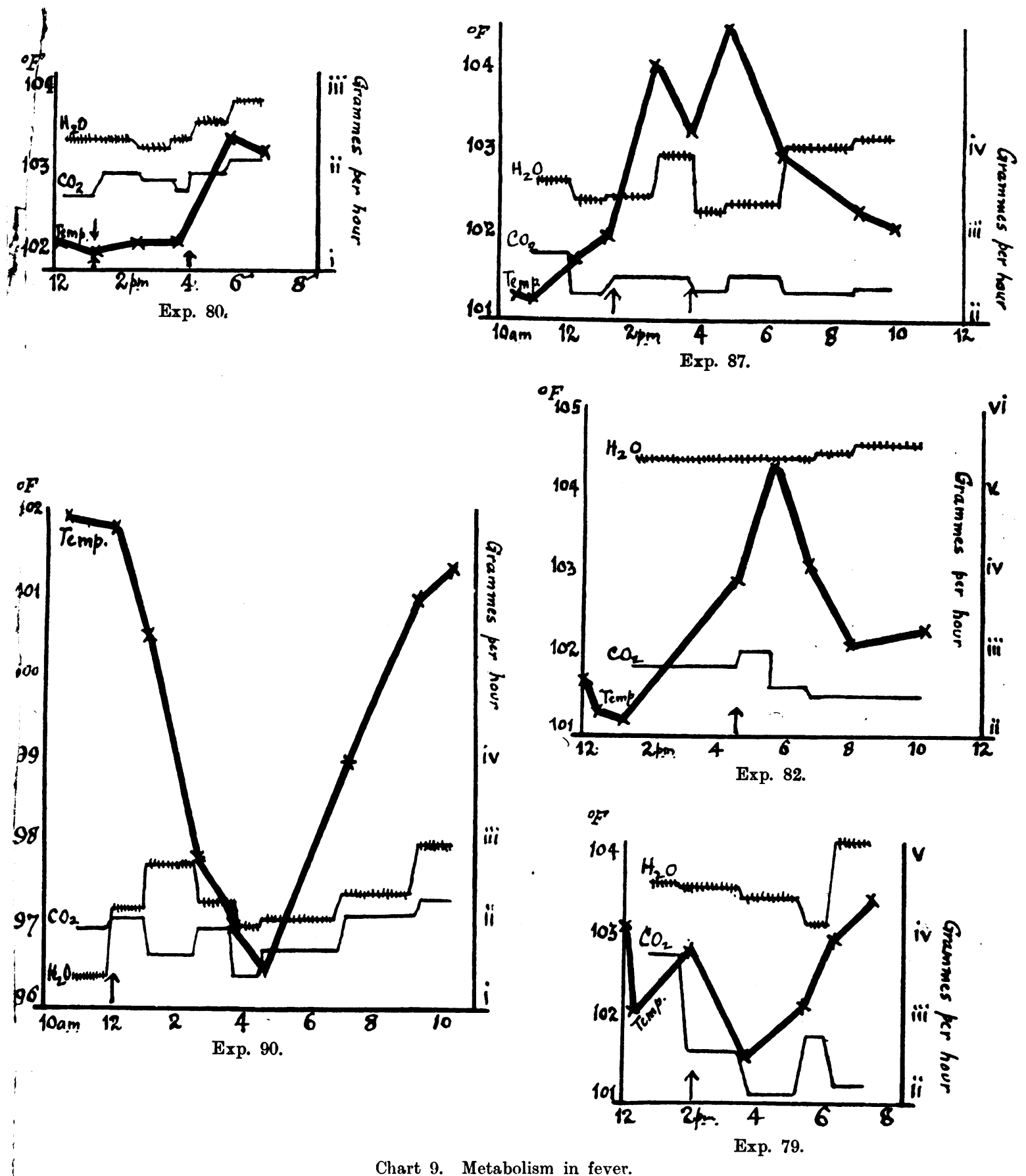

Chart 9. Metabolism in fever.

\begin{tabular}{|c|c|c|c|c|c|c|}
\hline \multirow{3}{*}{ Exp. } & \multirow{3}{*}{$\begin{array}{l}\text { Date } \\
\text { 24. } \text { III. } 13\end{array}$} & \multicolumn{2}{|c|}{ T. of air } & \multirow{3}{*}{$\begin{array}{c}\text { Rabbit } \\
\mathbf{5 9}\end{array}$} & \multirow{3}{*}{$\begin{array}{l}\text { Weight } \\
1600 \text { gms. }\end{array}$} & \multirow[b]{2}{*}{ Injection } \\
\hline & & Dry & Wet & & & \\
\hline & & $13 \cdot 5^{\circ} \mathrm{C}$ & $10^{\circ} \mathrm{C}$ & & & $\begin{array}{l}0.00018 \mathrm{gm} \text {. wet B.c.c. culture }(=0.0000176 \mathrm{gm} \text {. } \\
\text { dry B.c.c.) in } 1 \text { c.c. Ringer }\end{array}$ \\
\hline 80 & 26. III. 13 & 15 & 11 & 60 & 1720 gms. & $\begin{array}{l}0.0001 \text { gm. wet B.c.c. culture }(=0.00001 \mathrm{gm} . \\
\text { dry bacteria) in } 1 \text { c.c. Ringer }\end{array}$ \\
\hline 82 & 28. III. 13 & $12 \cdot 5$ & 10 & 43 & 1550 gms. & $\begin{array}{l}0.00013 \text { gm. B.c.c. sulphate powder }(=0.000005 \\
\text { gm. dry bacteria) in } 1 \text { c.c. Ringer }\end{array}$ \\
\hline 87 & 7. IV. 13 & $15 \cdot 4$ & $10 \cdot 7$ & 52 & 1870 gms. & $\begin{array}{l}\text { Two separate injections of "pyrotoxin" (Sebas- } \\
\text { tiani) solution }\end{array}$ \\
\hline 90 & 9. IV. 13 & $14 \cdot 5$ & $10 \cdot 3$ & 59 & 1590 gms. & $\begin{array}{c}0.05 \text { gm. B.c.c. sulphate powder }(0.002 \mathrm{gm} \text {. dry } \\
\text { bacteria) in l c.c. Ringer } \\
\text { (B.c.c. denotes } B \text {. coli communis })\end{array}$ \\
\hline
\end{tabular}


Rabbit 41). As previously stated bacterial pyrogen resists boiling. This fact was confirmed by experiment (see Experiment 45, Rabbits 43 and 44). When kept in the form of paste exposed to the air, the pyrogen of B.typhosus gradually diminishes in power (Hort and Penfold), but when kept dry in powder form the power of the pyrogen of $B$. coli to induce fever (or in large doses collapse) is, I find, maintained. Drying on the water-bath was found to produce no obvious diminution in potency. It is insoluble in absolute alcohol (see Experiment 70) and its potency is diminished by short contact with absolute alcohol (Experiment 70). It is insoluble in dry ether (see Experiments 53 and 55), but an extract obtained with wet ether produced a moderate pyretic effect (Experiment 46). When a moderately strong solution was filtered through a $7 \%$ collodion filter (made by soaking filter papers in a $7 \%$ solution of collodion in Glacial Acetic Acid, then washing out the acid in running water) at a pressure of $30 \mathrm{lbs}$. to the square inch, no detectable pyrogen passed the filter (Chart 6, Experiment 83); but when a fairly strong solution was filtered a trace equivalent to about $1 / 1000$ the original amount of pyrogen passed through the filter (Experiments 71 and 74).

Similarly on the addition of colloidal solution of iron to a solution of $B$. coli-pyrogen containing sodium sulphate most of the pyrogen was apparently precipitated with the iron, the filtrate only showing the presence of a trace of pyrogen (Experiment 63). Thus an effect commensurate with that produced by the injection of $0.00001 \mathrm{gm}$. was obtained from the filtrate from $0.02 \mathrm{gm}$., indicating that only about $1 / 2000$ of the original pyrogen was left in solution.

With a view to determining the chemical nature of the body responsible for the rise in body temperature, the filtrate in Experiment 71 , obtained by filtration of a "pyrogen" solution through a loose collodion filter, and "pyrotoxin" prepared according to Sebastiani, were examined. The results obtained in both cases were:

1. Esbach's Reagent-no precipitate.

2. Biuret Test-negative.

3. Strong $\mathrm{HNO}_{3}$. On floating on strong $\mathrm{HNO}_{3}$ a faint green ring at the junction of the liquids was seen and just above the green ring a faint purple ring.

4. Millon's Reagent. On adding the reagent a white precipitate appeared which dissolved in excess of the reagent. The white precipitate also dissolved on warming. No pink colouration occurred.

5. Adamkiewicz (Glyoxylic) Reaction-negative. 
6. Phosphotungstic Acid-no precipitate but very faint clouding of the solution.

7. Sulphur test with $\mathrm{NaOH}$ and Lead Acetate. No reaction.

8. With $\mathrm{KNO}_{2}$ and acid, gas bubbles given off, probably indicating $\mathrm{NH}_{2}$ group.

9. On heating, a white substance was left which, on further heating, yielded pungent fumes with an odour like some fatty acid such as butyric. On further heating "ammoniacal" fumes indicating nitrogen, and on further heating, charring indicating carbon.

A sufficient quantity to undertake further chemical analysis has not yet been obtained.

Many of the above tests confirm observations made by Sebastiani (1912).

Discussion of Results. From the above cited experiments it will be seen that a substance can be obtained from $B$. coli which, on injection in a minimal amount of Ringer's solution, will induce fever or collapse according to the dose given-a dose equivalent to $0.000004 \mathrm{gm}$. of bacterial bodies producing fever, and $0.002 \mathrm{gm}$. producing marked collapse or even death. As the bulk of the weight of the bacteria is something else than pyrogen (compare Sebastiani, 1912), the toxicity of the active substance must be extremely potent.

A comparison of Experiments 48 and 52 shows the relative potency of the bacterial powder and the supernatant liquid in which the bacteria had been suspended, and from which they had been separated by centrifuging. Allowing for idiosyncrasy of the rabbit and taking Rabbit 43 (Experiment 48) and Rabbit 43 (Experiment 52) as giving approximately the same reaction, $0 \cdot 1$ c.c. of the supernatant fluid (Experiment 48) gave an equivalent effect to $0.0001 \mathrm{gm}$. B. coli communis Sulphate Powder (Experiment 52) which contained 0.000004 gm. dry B. coli communis.

On the other hand, in Experiment 59, the supernatant fluid used was obtained as follows:

40 c.c. distilled water were added to paste containing $0.72 \mathrm{gm}$. dry bacteria.

$\therefore 1$ c.c. $=$ Extract of $0.018 \mathrm{gm}$. dry bacteria (approx. $0.02 \mathrm{gm}$.).

Again: in the preparation of pyrotoxin according to Sebastiani's method, a suspension of $B$. coli communis was made, and of this 25 c.c. were taken which contained $0.0723 \mathrm{gm}$. dry bacteria and, in the preparation of the pyrotoxin, this 25 c.c. were diluted to 154 c.c. 
This 154 c.c. of "pyrotoxin" solution contained the extract of $0.0723 \mathrm{gm}$. dry bacteria, or 1 c.c. contained the extract of approximately $0.0005 \mathrm{gm}$. dry bacteria.

1 c.c. of the pyrotoxin solution (Sebastiani) gave the same pyrogenic effect as 0.00001 gm. B. coli communis Sulphate Powder $=0 \cdot 0000004 \mathrm{gm}$. dry bacteria.

It is quite probable that the bacterial protoplasm contains many poisons which possess different properties. For example, Sebastiani states that he succeeded in separating a depressing body from the pyrotoxin with alcohol.

Experiment 48, Rabbit 44, and Experiment 83, Rabbit 54, show that there is present in Bacillus coli communis a substance of a paralysing nature for the death of animal 44 in Experiment 48 occurred with a temperature of $102^{\circ} \mathrm{F}$., and it is in all probability this body and not the true pyrogen which is responsible for the muscular weakness in the legs often exhibited by the animals. The sudden death of animal 44 in Experiment 48 seems to show that in this case the supernatant fluid took up from the bacteria to a specially large degree a substance having a very severe paralytic action on the body; for one hour after the injection the animal's rectal temperature had risen less than $2^{\circ} \mathrm{F}$. and $1 \frac{1}{2}$ hours later at the death of the animal had only fallen $1^{\circ} \mathrm{F}$. below the animal's temperature at the moment of injection.

The exact chemical nature of the pyrogenetic body has not yet been determined, but from the observations of Centanni (1894), Kiliani (1911) and Sebastiani (1912) it is not protein in nature. It appears, however, colloidal or adherent to bodies in the colloidal state.

It is possible that in the case of burns to the body, substances of a similar nature to bacterial pyrogen are set free in the body and give rise to the fever seen in milder cases and the collapse seen in severe cases. It has been shown by Heyde (1911) that in cases of severe burning there are demonstrable in the urine bodies of a nature similar to the putrefactive amines of the human body. A few experiments in the present research undertaken on this point indicate that when muscle is heated to $200^{\circ} \mathrm{C}$. there is a body (or bodies) liberated which exerts an action similar to that produced by injecting a bacterial emulsion. This result was not obtained by subjecting skin to a temperature of $200^{\circ} \mathrm{C}$. nor was the effect obtained by injecting muscle which had been heated to $100^{\circ} \mathrm{C}$. and $150^{\circ} \mathrm{C}$. The sudden fever and collapse seen in cases where an abscess bursts into the peritoneal or pleural cavity is clearly attributable to the rapid absorption of bodies 
contained in the pus or liquor puris or both and which had previously been kept out of the body by the wall of the abscess. The non-septic rise in temperature, which is often seen early in cases of simple fracture with a great deal of effusion, in the first 12 hours of the puerperium, in cases of extensive internal haemorrhage, and after most major operations associated with some degree of tissue destruction, may similarly be due to the entry into the bloodstream of the products of cell disintegration which act in the same way as bacterial pyrogen.

The fact that $\mathrm{Ca}$ forms an inert salt with these bodies may account for the so-called antagonism of $\mathrm{Ca}$ for pyrogen noted by Hort and Penfold (1912), and may be found of value clinically. So far a few experiments only have been performed and no clear result is yet forthcoming.

That fever-producing substances can be liberated by autolysis of the bodies of bacteria is seen in the method of preparation of Sebastiani's pyrogen (supra, p. 171), which has been shown to be much more potent than a simple non-colloidal watery extract of dead bacteria (vide supra, pp. 186 and 190).

Undoubtedly some of the results noted above with ferments and with proteoses and other products of protein degradation can be attributed to the association as impurities of simple bodies having a pyrogenic action. In this connection it is particularly interesting to note that Kühne (1893) found that pure enzymes did not exert pyrogenic action.

The results of the skin reaction obtained in the fever studied confirm those observed in man by Maragliano $(1888,1890)$ with the plethysmograph, and those obtained by Geigel in man with the thermo-electric method. In the experiments recorded above a different type of fever was examined, all the stages of which were studied in a short space of time (generally about 3 or 4 hours) under the same conditions of atmospheric temperature, humidity and pressure, and uninfluenced by the many considerations, such as diet, attention, etc., which must enter into a study protracted over days.

The result obtained in collapse confirms the generally accepted clinical facts.

With regard to variation in heat production, the results obtained confirm in the main those of other observers, Jaquet (1903), Krehl and Matthes (1897), Loewi (1904), May (1893), von Noorden (1907), and Richter, who state that in the initial stage of pyrexia from infection, heat production is little increased and that the excess of combustion does not exceed $25 \%$. In collapse with fall of temperature a diminution in heat production has always been observed. 
A point of further interest is the pyretic response to alterations in dosage. Here we see in response to increase in dosage of pyrogen beyond a certain point an actual diminution in the pyrexia produced and with a certain dose no pyrexia whatever, while the animal responds to a still larger dose with a subnormal temperature. This kind of phenomenon is met with clinically every day and is at first sight puzzling. In many epidemics of infectious diseases cases often occur showing a high body temperature with perhaps no other signs of intoxication, while other cases are manifestly very ill, yet the temperature is either normal or perhaps subnormal. The response of an old animal with a subnormal temperature to a dose of pyrogen which in a younger animal would give a sharp rise in temperature is met with clinically in the human being in many diseases, e.g., the afebrile pneumonia of old people.

\section{Conclusions.}

1. A definite rise in body temperature is obtainable by injecting a minute amount (as small as $0.000004 \mathrm{gm}$.) of bacterial substance in a small quantity of Ringer's solution and a definite collapse or even death is obtained with larger doses.

2. The body or bodies in the bacteria responsible for the rise in temperature are either of a colloidal nature or adherent to colloids and may be almost entirely separated by a collodion filter. They are soluble in water and saline solutions. They are not destroyed by boiling or by dry heat of $110^{\circ} \mathrm{C}$. They are insoluble in ether, and are not affected by prolonged contact with ether. They are insoluble in absolute alcohol, and their potency diminishes after contact with absolute alcohol.

3. The rise in temperature produced lasts a few hours and is principally due to a diminution of heat loss, heat production remaining sometimes unaffected and sometimes increased. The fall in temperature in collapse when large doses of the bacterial extract were administered is due to a diminution in production-heat loss being also diminished.

4. In animals in which the brain stalk has been severed distal to the Optic Thalamus no rise of temperature occurred after the injection of an ordinary pyretic dose.

My best thanks are due to Professor C. J. Martin, F.R.S., for his valuable advice and assistance during the progress of this work. 


\section{REFERENCES.}

Barbour (1912). Arch. f. Exper. Pathol. u. Pharm. Lxix. (1).

Bergmann (1868). Petersburger Med. Zeitschr.

Billroth (1866). Beobachtungen über Wundfieber. Langenbeck's Arch. f. klin. Chirurg. (1872) XII. 610.

Buchner (1891). Tuberculinreaction durch Proteine nicht specifischer Bacterien. München. med. Wochenschr. p. 841.

Centanni (1894). Ueber Infectionsfieber. Das Fiebergift der Bacterien. Deutsche med. Wochenschr. Nos. 7 and 8.

EDelberG (1880). Über die Wirkungen des Fibrinfermentes in Organismus. Arch. f. Exper. Path. xIr. 283.

Frese (1866). Experimentelle Beiträge zur Aetiologie des Fiebers.

Frienberger, E. und Mita, S. (1911). Ueber Anaphylaxie. XVIII, Anaphylactische Fieberreaction. Ztschr. f. Immunitätsforschung, x. 216.

Frothingham, C. and Minot, G. (1912). The normal temperature of Rabbits. Amer. Journ. of Physiol. xxx. 430.

GeIGEL (-). Die Hauttemperatur in Fieber. Verh. d. physik. med. Ges. in Würzburg, xxir. No. 1.

HALDANE, J. S. (1892). A new form of Apparatus for measuring the respiratory exchange of animals. Journ. of Physiol. xIII. 419.

HermanN (1866). Experimentelle Studien über die Wirkung faulender Stoffe auf den thierischen Organismus.

HEYDE, M. (1911). Über den Verbrennungstod und seine Beziehungen zum anaphylaktischen Shock. Zentralbl. f. Physiol. xxv. 441-444.

Hildebrandt, H. (1890). Zur Wirkung der hydrolytischen Fermente. Virchow's Archiv, CXxI. 1.

Hont, E. C. (8. II. 1913). Vaccines and Fever. Brit. Med. Journ. I. 265.

Hort, E. C. and Penfold, W. J. (16. xII. 1911). The dangers of Saline Injections. Brit. Med. Journ. II. 1510.

Hort, E. C. and Penfold, W. J. (1912). A critical Study of Experimental Fever. Proc. Roy. Soc. London, B. Lxxxv. 174.

Hort, E. C. and Penfold, W. J. (1912). The pyrogenetic properties of B. typhrsus. Brit. Med. Journ. II. 1300.

HuEPPE (1893). Ueber Giftbildung durch Bacterien und über giftige Bacterien. Berlin. klin. Wochenschr. p. 409.

JAQUet (1903). Der respiratorische Gaswechsel. Ergebnisse d. Physiol. II. (Biochemie) 457.

Kalinin, A. A. (1897). Untersuch. ü. d. Ausscheidung von $\mathrm{CO}_{2}, \mathrm{~N}$, und $\mathrm{P}$ und $\mathrm{d}$. O-Verbrauch in der Latenzperiode des Fiebers bei Kaninchen und Hunden nach subcutaner Infection mit Bouillon-culturen von Pyocyaneus- und Diphtherie-bacillen. Centralbl. f. allgemein. Path. viII. 518-525.

Kiliani (1911). Technische Fiebermittel-B. coli. Arch. int. d. pharmacodynamie et de thérap. p. 333.

KLempereR, G. (1892). Die Beziehungen verschiedener Bacteriengifte zur Immunisirung und Heilung. Ztschr. f. klin. Med. xx. 165-169.

Косн (1890). Weitere Mitteilungen über ein Heilmittel gegen die Tuberculose. Deutsche med. Wochenschr. (Extra-ausgabe) p. 1029.

Kraus, F. (1907). Article "Fever and Infection" in von Noorden's Metabolism and Practical Medicine, Eng. trans. II. 120. 
Krehl, L. und Matthes, M. (1897). Wie ensteht die Temperatursteigerung des fiebernden Organismus? Arch. f. Exp. Path. u. Pharm. xxxviII. 284.

Küнne (1892-1893). Erfahrungen über Albumosen und Peptonen, III. Albumosen in Bacterien. Ztschr. f. Biologie (1892) xxIx. 24. 221.

Langlois (1904). Article "Fjèvre" in Richet's Dictionnaire de Physiologie, vi. 423.

Loew (1904). Pharm. des Wärmehaushalts. Ergebnisse der Physiologie (Biochemie), III. 332.

Maragliano (1888, 1890). Das Verhalten der Blutgefässe in Fieber und bei Antipyrese. Ztschr. f. klin. Med. (1888) xIv. 309; (1890) xvII. 291.

MatThes (1895). Ueber die Wirkung einiger subcutan einverleibten Albumosen. Deutsch. Arch. f. klin. Med. LIv. 39.

MAY (1893). Der Stoffwechsel in Fieber. Ztschr. f. Biol. xxx. 1.

Müller, J. Quoted from Burdon Sanderson.

NebelthaU (1895). Kalorimetrische Untersuchungen an hungernden Kaninchen in fieberfreien $u$. fieberhaften Zustande. Ztschr. f. Biol. XXxI. 293.

Noorden, C. von (1907). Metabolism and Practical Medicine, Ir. 143.

Panum (1855-56). Zur Lehre von der putriden oder septischen Infectionen. Schmidt's Jahrbiucher (1855).

- Sepsin, Bibliotek for Laeger (1856). (Quoted from Sims Woodhead, Bacteria and their Products (189]).)

RIChTER (-). "Fieber" in Handbuch der Biochemie hgb. von C. Oppenheimer, IV. 104 .

RÖmer (1891). Tuberculinreaction durch Bacterienextracte. Wiener klin. Wochenschr. p. 835.

Rosenthal, W. (1893). Thermo-electr. Untersuchungen über die Temperaturvertheilung im Fieber. Arch. f. Anat. u. Physiol. (Physiol. Abtheil) Suppl. p. 217.

Rouques (1893). Substances thermogènes extraits des tissus animaux sains. Paris, 1893. Quoted from Burdon Sanderson.

Roussy (1910). Quoted from Adami's Principles of Pathology, p. 483.

Royal Commission on Tuberculosis (1913). Appendix to Final Report of Royal Commission on Human and Animal Tuberculosis. (L. Cobbett and Stanley Griffith.) London.

Burdon Sanderson (1867). On the Process of Fever.

- (1872). On Infective Inflammations. Appendix to Report of the Medical Officer to the Privy Council (1876). Quoted also by Burdon Sanderson (1896). I. 139 .

Sebastiani, V. (1912). I varii tipi febrili riprodotti con un' unica pirotossino batterica. Lo Sperimentale, LXVI. 137.

SENATOR (1873). Untersuchungen über den fieberhaften Prozess und seine Behandlung. Berlin.

Traube (1855). Deutsche Klin.; quoted from Burdon Sanderson (1896).

— (1864). Zur Fieberlehre. Gesammelte Beiträge, II. 679.

Traube und Jochmann (1855). Zur Theorie des Fiebers. Gesammelte Beiträge, II. 286 .

Virchow (1853). Handbuch der Pathologie, p. 36.

Weber, O. (1910). Quoted from Adami's Principles of Pathology, 1910, p. 483.

Zupnik, L. (1903). Ueber die Tuberculinreaction. Arch. f. klin. Med. Lxxvi. 290. 